\title{
Preferensi Konsumen terhadap Atribut Kualitas Tiga Jenis Sayuran Indigenous di Jawa Timur, Indonesia
}

\author{
Consumers' Preference on Quality of Three Indigenous Vegetables \\ in East Java, Indonesia
}

Kartika Yurlisa $^{1 *}$, Moch. Dawam Maghfoer ${ }^{1}$, Nurul Aini ${ }^{1}$, dan Wiwin Sumiya Dwi Yamika ${ }^{1}$

Diterima 16 Agustus 2017/Disetujui 07 Februari 2018

\begin{abstract}
Indigenous vegetable production is a primary source of revenue for micro-scale vegetable farmers in East Java Province. Despite the, information about consumer preference on the quality attribute of the indigenous vegetables is still lack. Thus, the study purposed to determine consumer preferences on the quality attribute of leafy greens basil, kenikir and watercress to improve the quality on the farm level. The research conducted through consumer survey in seven sites, namely Surabaya, Malang, Kediri, Madiun, Jember, Bojonegoro, Pamekasan, East Java Indonesia from July to August 2017. The site selection based on sociocultural and the composition of diverse communities. From seven sites, a total of 210 female respondents interviewed randomly. Consumer preferences on the quality attributes concluded by the method based on rank orders and analyzed with Chi-square. The experimental results showed that consumer preference for quality attributes depend on the vegetable. For basil: leaf color was light green, a large number of leaves, without a flower, medium leaf size (3.5 cm diameter), number of branches/stalk, no spicy taste, and smells stung. For kenikir: leaf color was light green, a large number of leaves, without a flower, medium smell, a large number of branches/stem, the texture of stem not fibrous, and no bitter taste. For watercress: leaf color was green, a large number of leaves, medium stem size, soft leaf, and slightly sweet flavor.
\end{abstract}

Keywords: basil, consumer preference, kenikir, vegetable quality, watercress

\begin{abstract}
ABSTRAK
Produksi sayuran indigenous merupakan sumber pendapatan penting bagi petani sayuran skala kecil di Provinsi Jawa Timur. Namun demikian, kriteria kualitas yang diinginkan oleh konsumen masih belum seluruhnya dipetakan, oleh sebab itu, pengkajian dilakukan agar dapat di identifikasi preferensi konsumen terhadap kualitas sayuran kemangi, kenikir dan selada air dalam rangka perbaikan kualitas di tingkat petani. Survei konsumen dilakukan di tujuh wilayah di Jawa Timur, yaitu Surabaya, Malang, Kediri, Madiun, Jember, Bojonegoro, dan Pamekasan pada bulan Juli sampai Agustus 2017. Pemilihan wilayah didasarkan pada sosiokultur dan komposisi masyarakat yang beraneka ragam. Dari 7 wilayah tersebut, wawancara dilakukan dengan total 210 responden wanita yang ditentukan secara acak. Preferensi pengguna terhadap sifat kualitas sayur-sayuran dianalisis menggunakan Chi-square. Hasil analisis menunjukkan bahwa, preferensi pengguna terhadap sifat kualitas tergantung pada jenis sayurannya. Sayur kemangi yang disukai adalah memiliki warna daun muda, jumlah daun banyak, ukuran daun medium (garis tengah $3.5 \mathrm{~cm}$ ), tidak terdapat bunga, total cabang/tangkai lebat, rasa tidak pedas, dan berbau menyengat. Sayur kenikir yang disukai adalah warna daun muda, jumlah daun banyak, tidak terdapat bunga, berbau sedang, jumlah cabang/tangkai banyak, tekstur batang tidak berserat, dan rasa tidak getir. Sayur selada air yang disukai adalah warna daun muda, jumlah daun banyak, ukuran batang sedang, berdaun lunak, dan rasa agak manis.
\end{abstract}

Kata kunci: kemangi, kenikir, kualitas sayuran, preferansi konsumen, selada air

${ }^{1}$ Fakultas Pertanian Universitas Brawijaya

Jl. Veteran, Malang 65145

E-mail : kartikayurlisa2@gmail.com (*Penulis korespondensi) 


\section{PENDAHULUAN}

Sayuran umumnya dikonsumsi mentah atau dimasak dengan tujuan utama memperoleh asupan zat gizi untuk menunjang aktivitas manusia. Kandungan gizi sayuran meliputi karbohidrat, protein, mineral, serat, vitamin, dan nutrisi lain (Soetiarso, 2010; Dias, 2012). Sayuran indigenous didefinisikan sebagai spesies sayuran lokal yang penting sebagai sumber pendapatan, pemenuhan gizi, kesehatan, dan sistem sosial tetapi belum sejajar dengan komoditas komersial (Keatinge et al., 2015).

Pemanfaatan sayuran indigenous merupakan salah satu alternatif solusi permasalahan malnutrisi. Sayuran indigenous memiliki potensi untuk dikembangkan karena dapat beradaptasi baik dalam kondisi lingkungan yang beragam (beraneka macam tanah, kondisi iklim tidak menentu dan dapat tumbuh pada kondisi tanah kurang subur) (D’Anna dan Sabatino, 2013), pengganti sumber gizi dan vitamin yang terjangkau harganya (Kwenin et al., 2011). Hasil studi yang telah dilakukan pada kandungan nutrisi sayuran indigenous umumnya menunjukkan kadar vitamin $\mathrm{C}$ dan total padatan yang tinggi (Mardiyani et al., 2017).

Kemangi, kenikir, dan selada air merupakan sayuran indigenous yang banyak di konsumsi. Dalam $100 \mathrm{~g}$ daun kemangi terkandung zat besi $2 \mathrm{mg}$, kalsium $45 \mathrm{mg}$, protein $4 \mathrm{~g}$, energi $46 \mathrm{kal}$, lemak $0.5 \mathrm{~g}$, karbohidrat $8.9 \mathrm{~g}$, fosfor $75 \mathrm{mg}$, vitamin C 50 $\mathrm{mg}$, vitamin B1 $0.08 \mathrm{mg}$, dan vitamin A 5000 SI (Soetiarso, 2010). Kandungan nutrisi daun kenikir adalah protein $22.81 \%$, kadar serat kasar 22\% dan kadar lemak 1.92\% (Irfai, 2013). Sementara hasil penelitian Salamah et al. (2011), menunjukkan selada air memiliki kadar protein $2.11 \%$, kadar lemak $0.22 \%$ dan kadar karbohidrat $1.90 \%$.

Indonesia ialah salah satu dari 17 negara mega biodiversitas (Pariona, 2018). Salah satu keanekaragaman hayati yang dimiliki Indonesia, yaitu sayuran indigenous. Perhatian masyarakat terhadap sayuran indigenous sebagai sayuran lokal Indonesia masih sangat kurang, akibatnya keberadaan kelompok sayuran indigenous kurang dikenal dan bahkan mulai terancam punah, dan cenderung digeser oleh sayuran komersial (Soetiarso, 2010), oleh karena itu, perlu penelitian pemanfaatan sayuran indigenous, khususnya bagaimana mengangkat potensi sehingga bisa bersaing dengan sayuran komersial.

Beberapa penyebab masih rendahnya pemanfaatan sayuran indigenous, di antaranya adalah bahan tanam yang diperlukan kurang tersedia, sedikitnya pengetahuan tentang cara budi daya, dan kecocokan sayuran indigenous dengan sistem budi daya tanaman yang tersedia (Soetiarso, 2010). Penyebab yang lain kemungkinan langkah penyusunan teknologi pertanian yang belum tepat, menyebabkan produk yang dirakit belum dimanfaatkan oleh pengguna atau membutuhkan waktu yang lama untuk memulai proses adopsi teknologinya (Mottaleb, 2018). Salah satu upaya agar teknologi yang dihasilkan bersifat implementatif adalah mempelajari perilaku pengguna, yang berhubungan dengan preferensi pengguna terhadap sifat-sifat keluaran dalam rangka perbaikan dan pengembangan produk baru (Adiyoga dan Nurmalinda, 2012).

Di antara komoditas sayuran indigenous yang lebih sering diperjualbelikan di pasar tradisional Jawa timur adalah kemangi, kenikir, dan selada air. Sayuran tersebut juga populer di tempat lain seperti di Jawa Barat (Santosa et al., 2015). Pertimbangan pemilihan ketiga komoditas tersebut didasarkan hasil survei pendahuluan kelimpahan sayuran indigenous di pasar tradisional (Maghfoer et al., 2017). Penelitian ini dilakukan untuk memperbaiki kualitas sayuran tersebut dengan cara mengkaji perilaku konsumen, termasuk memahami bagaimana preferensi konsumen terhadap kualitas produk. Penelitian bertujuan untuk mempelajari preferensi pengguna terhadap atribut kualitas tiga macam sayuran indigenous daun yakni kemangi, kenikir, dan selada air. Pengambilan keputusan yang dilakukan konsumen untuk memilih sayuran minor/lokal sangat dipengaruhi oleh atribut kualitas produk, seperti kesegaran, rusak tidaknya produk, nilai gizi maupun kebersihan (Hussin et al., 2010), oleh karena itu, penyusunan urutan atribut kualitas dibutuhkan oleh konsumen untuk mengetahui pertimbangan mereka dalam memilih/membeli sayuran lokal.

\section{BAHAN DAN METODE}

Pada uji pendahuluan, semua sayuran indigenous yang tersedia di 80 pasar tradisional 
disurvei dan didokumentasikan. Telah terdokumentasikan 48 spesies sayuran indigenous dari 43 genus dan 25 famili. Kemudian dipilih tiga spesies, yaitu kenikir (Cosmos caudatus Kunth.), selada air (Nasturtium officinale R. Br.) dan kemangi (Ocimum americanum L.) sebagai spesies sayuran yang sering diperjual-belikan dan memberi keuntungan di pasar.

Penelitian melalui survei preferensi konsumen dilakukan pada bulan Juli hingga Agustus 2017 di tujuh wilayah di Jawa Timur yaitu Surabaya, Malang, Kediri, Madiun, Jember, Bojonegoro, dan Pamekasan (Madura). Pemilihan wilayah berdasarkan pada sosiokultur dan komposisi masyarakat yang beraneka ragam. Wawancara dilakukan pada responden konsumen yang berbelanja di pasar tradisional, pada setiap wilayah dipilih 9-12 pasar tradisional. Pemilihan pasar tradisional berdasarkan kemudahan untuk mengakses dan besarnya volume penjualan sayuran. Pada satu pasar tradisional diwawancarai $1-6$ responden, sehingga tiap wilayah didapatkan total 30 responden, dan total seluruh responden penelitian yaitu 210 orang. Responden pada percobaan ini yaitu penguna yang berprofesi sebagai ibu rumah tangga. Responden tersebut dipilih dengan alasan mempunyai peran pada pemilihan menu konsumsi keluarga dan memiliki pengetahuan yang lebih banyak mengenai pemanfaatan sayuran indigenous.

Metode penghimpunan informasi melalui wawancara dengan kuisioner terstruktur. Pengambilan data dilakukan dengan melakukan wawancara langsung dengan responden di pasar maupun wawancara langsung ke rumah konsumen. Data yang dikumpulkan di penelitian ini meliputi (1) data responden yakni umur, tingkat pendidikan, pekerjaan, total anggota keluarga, dan jumlah pengeluaran per bulan, (2) preferensi responden terhadap kriteria sifat kualitas keluaran dan tingkat pertimbangan pengguna dalam pembelian sayuran indigenous, dan (3) hambatan konsumsi sayuran indigenous. Sifat kualitas produk sayuran, (a) kemangi, meliputi warna daun, ukuran daun, jumlah daun, bau, bunga, jumlah cabang/tangkai dan rasa. (b) kenikir, meliputi warna daun, jumlah daun, bau, bunga, tekstur batang, jumlah cabang/tangkai serta rasa. (c) selada air, meliputi warna daun, ukuran batang, total daun, kekerasan daun serta rasa. Atribut kualitas kemangi dan selada air berdasarkan penelitian yang dilakukan Soetiarso (2010). Untuk kenikir, atribut kualitas merupakan standar atribut kualitas yang disusun oleh peneliti.

Analisis pertimbangan konsumen dalam melakukan pembelian komoditas menggunakan metode berdasarkan peringkat (Ameriana et al., 1998), dasar preferensi pengguna yaitu kelompok tiap atribut kualitas keluaran yang dihitung dengan skala nominal serta ordinal melalui pengujian statistika non parametrik, yaitu pengujian Chi-square (Siegel, 1997), dengan tingkat kepercayaan 95\% $(\alpha=0.05)$. Perhitungan menggunakan Microsoft Excell.

$X^{2}=\sum_{i=1}^{k} \frac{\left(O_{i}-E_{i}\right)^{2}}{E_{i}}$ di mana: $\chi 2=$ Angka yang menunjukkan keterangan hasil observasi, $O i=$ Total kasus yang diobservasi pada kategori kei, $E i=$ Total kasus yang diharapkan pada kategori ke-i, jika $H O$ benar, $H O=$ Proporsi kasus-kasus dalam setiap kategori yaitu sama, $k=$ total kategori.

\section{HASIL DAN PEMBAHASAN}

\section{Karakteristik Responden}

Tabel 1 menunjukkan bahwa sebagian besar responden berusia antara 41-50 tahun. Umumnya responden yang berusia muda (20-40 tahun) lebih sedikit mengonsumsi sayuran indigenous dibandingkan yang berusia menengah dan tua ( $>40$ tahun). Sebagian besar responden $(68.10 \%)$ bekerja di bidang informal dan ibu rumah tangga. Separuh dari responden dikelompokkan sebagai keluarga kecil dengan total anggota keluarga $\leq 3$ orang $(43.81 \%)$.

Dilihat dari tingkat pendidikan formal, $37.62 \%$ responden mempunyai tingkat pendidikan akhir SD (Sekolah Dasar). Dari jumlah pengeluaran per bulan, umumnya responden (73.3\%) mempunyai jumlah pengeluaran umumnya rendah, yaitu $\leq \quad R p$ 2000000 ,- per bulan. Berkaitan dengan total pengeluaran responden yang relatif kecil, tampaknya motif pembelian sayuran indigenous berkaitan dengan harga sayur yang murah. Hampir sebagian besar konsumen menyatakan sayuran indigenous bisa dibeli dengan harga yang lebih rendah dibandingkan sayuran komersial. Sejumlah 2.61-15.73\% responden tidak membeli sayuran tersebut di pasar tradisional, melainkan menanam sendiri. 
Karakteristik responden untuk sayuran indigenous berbeda antar 7 kota dan kabupaten. Mayoritas responden berusia $<40$ tahun di wilayah Malang, Bojonegoro dan Jember, responden berusia 41-50 tahun berada di wilayah Surabaya, Kediri dan Madiun dan mayoritas responden berusia $>40$ tahun berada di wilayah pamekasan. Latar belakang pendidikan mayoritas responden SD dan SMA di wilayah Malang, Kediri dan Madiun, berpendidikan SD di wilayah Bojonegoro dan Jember, berpendidikan SMP di wilayah Pamekasan, sedangkan mayoritas responden berpendidikan SMA dan Universitas di wilayah Surabaya. Mayoritas responden bekerja sebagai ibu rumah tangga, kecuali untuk wilayah Pamekasan (mayoritas bekerja di sektor swasta). Mayoritas responden merupakan keluarga kecil (jumlah anggota keluarga $\leq 3$ orang), kecuali untuk wilayah Bojonegoro (4 orang) dan Jember (5 orang). Mayoritas responden mempunyai total pengeluaran bulanan yang umumnya rendah $(\leq$ Rp. 2000 000,-), kecuali di wilayah Surabaya dan Bojonegoro, responden memiliki total pengeluaran bulanan yang relatif menengah (Rp. 2000 000,- Rp. 4000 000,-).

\section{Preferensi Konsumen terhadap Sayuran Indigenous}

Sayuran indigenous kemangi pada umumnya dikonsumsi sebagai lalapan, sayuran tersebut tidak dimasak. Sekitar 37.88-74.89\% konsumen memilih sayuran selada air dan kenikir yang direbus dan disajikan sebagai urap, pecel dan gado-gado. Sementara yang lainnya memilih untuk mengolah selada air menjadi tumisan $(29.80 \%)$ dan lalapan $(20.71 \%)$. Untuk konsumen, atribut kualitas dapat menjadi acuan untuk melakukan pembelian sayuran (Matenge et al., 2012).

Tabel 1. Karakteristik responden

\begin{tabular}{|c|c|c|c|c|c|c|c|c|c|c|}
\hline \multirow{2}{*}{\multicolumn{2}{|c|}{ Karakteristik responden }} & \multicolumn{7}{|c|}{ Daerah penelitian } & \multirow{2}{*}{ Total } & \multirow{2}{*}{$\%$} \\
\hline & & MLG & SBY & KDR & MDN & $\mathrm{BJN}$ & JBR & PKN & & \\
\hline \multirow{5}{*}{$\begin{array}{l}\text { Umur } \\
\text { (tahun) }\end{array}$} & $\leq 30$ & 4 & 4 & 4 & 2 & 15 & 0 & 0 & 29 & 13.81 \\
\hline & $31-40$ & 11 & 6 & 7 & 3 & 15 & 17 & 0 & 59 & 28.1 \\
\hline & $41-50$ & 5 & 10 & 11 & 16 & 0 & 13 & 11 & 66 & 31.43 \\
\hline & $51-60$ & 3 & 7 & 7 & 7 & 0 & 0 & 14 & 38 & 18.1 \\
\hline & $>60$ & 7 & 3 & 1 & 2 & 0 & 0 & 5 & 18 & 8.57 \\
\hline \multirow{4}{*}{ Pendidikan } & SD & 13 & 5 & 8 & 11 & 24 & 18 & 0 & 79 & 37.62 \\
\hline & SMP & 2 & 4 & 7 & 8 & 0 & 0 & 23 & 44 & 20.95 \\
\hline & SMA & 12 & 11 & 15 & 10 & 0 & 12 & 5 & 65 & 30.95 \\
\hline & Universitas & 3 & 10 & 0 & 1 & 6 & 0 & 2 & 22 & 10.48 \\
\hline \multirow{3}{*}{ Pekerjaan } & PNS & 0 & 5 & 0 & 1 & 0 & 2 & 2 & 10 & 4.76 \\
\hline & Swasta & 6 & 11 & 9 & 3 & 0 & 0 & 28 & 57 & 27.14 \\
\hline & $\begin{array}{l}\text { Ibu rumah } \\
\text { tangga }\end{array}$ & 24 & 14 & 21 & 26 & 30 & 28 & 0 & 143 & 68.1 \\
\hline \multirow{5}{*}{$\begin{array}{l}\text { Jumlah } \\
\text { anggota } \\
\text { keluarga } \\
\text { (orang) }\end{array}$} & $\leq 3$ & 19 & 16 & 11 & 16 & 0 & 3 & 27 & 92 & 43.81 \\
\hline & $\overline{4}$ & 5 & 8 & 13 & 8 & 30 & 1 & 0 & 65 & 30.95 \\
\hline & 5 & 0 & 5 & 3 & 4 & 0 & 17 & 0 & 29 & 13.81 \\
\hline & 6 & 3 & 1 & 1 & 1 & 0 & 9 & 0 & 16 & 7.62 \\
\hline & $>6$ & 3 & 0 & 2 & 1 & 0 & 0 & 3 & 8 & 3.81 \\
\hline \multirow{3}{*}{$\begin{array}{l}\text { Pengeluara } \\
\mathrm{n} / \text { bulan } \\
(\mathrm{Rp})\end{array}$} & $\leq 2.000 .000$ & 21 & 13 & 26 & 29 & 5 & 30 & 30 & 154 & 73.33 \\
\hline & $\begin{array}{l}>2.000 .000 \\
-4.000 .000\end{array}$ & 9 & 16 & 4 & 1 & 17 & 0 & 0 & 47 & 22.38 \\
\hline & $>4.000 .000$ & 0 & 1 & 0 & 0 & 8 & 0 & 0 & 9 & 4.29 \\
\hline
\end{tabular}

Keterangan: Malang (MLG), Surabaya (SBY), Kediri (KDR), Madiun (MDN), Bojonegoro (BJN), Jember (JBR), Pamekasan (PKN). 


\section{Kemangi}

Tingkat kepentingan dan preferensi konsumen pada sifat kualitas kemangi disajikan pada Tabel 2. Urutan kepentingan memperlihatkan bahwa konsumen menempatkan warna daun, jumlah daun dan ukuran daun pada pertimbangan pertama, kedua dan ketiga dalam memilih/membeli kemangi. Ada tidaknya bunga, total cabang/tangkai, dan rasa pada urutan keempat, kelima, dan keenam. Urutan terakhir (ketujuh) yang dipertimbangkan oleh konsumen adalah bau.

Hasil uji atribut kualitas kemangi yang meliputi warna daun, jumlah daun, ukuran daun, jumlah cabang/tangkai, rasa, serta bau terlihat ada beda nyata $(\alpha=0.01)$, di hasil uji ada tidaknya bunga nyata $(\alpha=0.05)$. Sesuai dengan preferensinya, mayoritas responden menginginkan kemangi berdaun hijau muda, berjumlah daun banyak, berukuran daun medium (garis tengah $=3.5 \mathrm{~cm}$ ), tidak memiliki bunga, bercabang/ bertangkai lebat, memiliki rasa tidak pedas, dan berbau menyengat.

Untuk mendapatkan sayuran kemangi yang sesuai dengan preferensi atribut kualitas di atas dapat dilakukan dengan beberapa teknik budidaya: (1) daun berwarna hijau muda diperoleh ketika panen dilakukan pada pucuk tanaman, (2) jumlah dan tangkai daun banyak didapat ketika sering melakukan pangkas produksi, (3) ukuran daun sedang diperoleh ketika melakukan panen pada ukuran daun yang sesuai dengan preferensi konsumen (4) produk sayur yang tidak memiliki bunga didapat ketika panen dilakukan sebelum memasuki umur berbunga, (5) rasa yang tidak pedas didapatkan ketika kondisi lingkungan tumbuh tidak tercekam, dan (6) berbau menyengat didapat ketika tanaman dalam kondisi tercekam, misalnya terpapar suhu udara panas. Selain teknik budidaya, dapat juga dilakukan perakitan varietas kemangi oleh para pemulia sesuai dengan preferensi atribut kualitas diatas.

\section{Kenikir}

Tingkat kepentingan dan preferensi pengguna pada sifat kualitas kenikir disajikan pada Tabel 3. Dari tingkat kepentingannya (ranking), konsumen memposisikan warna daun pada urutan pertama untuk memilih/ membeli kenikir. Peringkat kedua dan ketiga yang menjadi pertimbangan konsumen untuk memilih kenikir adalah jumlah daun dan bunga. Selanjutnya berturut-turut diikuti memiliki bau, jumlah cabang/tangkai banyak, tekstur batang, dan rasa.

Tabel 2. Tingkat kepentingan dan preferensi konsumen pada atribut kualitas kemangi

\begin{tabular}{|c|c|c|c|c|c|c|c|}
\hline \multicolumn{2}{|c|}{ Urutan Kepentingan } & \multirow{2}{*}{ Atribut Kualitas } & \multirow{2}{*}{ Kategori } & \multirow{2}{*}{$\mathrm{n}$} & \multirow{2}{*}{\multicolumn{2}{|c|}{$\chi$ Hitung }} & \multirow{2}{*}{$\chi$ Tabel } \\
\hline Peringkat & Rerata & & & & & & \\
\hline \multirow[t]{2}{*}{ I } & 2.16 & Warna daun & Hijau tua & 64 & 28.31 & ** & 3.84 \\
\hline & & & Hijau muda & 140 & & & \\
\hline \multirow[t]{2}{*}{ II } & 2.49 & Jumlah daun & Banyak & 183 & 128.65 & $* *$ & 3.84 \\
\hline & & & Sedang & 21 & & & \\
\hline \multirow[t]{3}{*}{ III } & 3.43 & Ukuran daun & $\operatorname{Besar}(\varnothing=4.5 \mathrm{~cm})$ & 49 & 51.56 & $* *$ & 5.99 \\
\hline & & & $\operatorname{Medium}(\varnothing=3.5 \mathrm{~cm})$ & 116 & & & \\
\hline & & & $\operatorname{Kecil}(\varnothing=2 \mathrm{~cm})$ & 39 & & & \\
\hline \multirow[t]{2}{*}{ IV } & 3.57 & Bunga & Ada bunga & 87 & 4.41 & $*$ & 3.84 \\
\hline & & & Tidak ada bunga & 117 & & & \\
\hline \multirow[t]{3}{*}{ V } & 4.95 & Jumlah & Lebat & 118 & 75.03 & $* *$ & 5.99 \\
\hline & & cabang/tangkai & Sedikit & 69 & & & \\
\hline & & & Tidak bercabang & 17 & & & \\
\hline \multirow[t]{2}{*}{ VI } & 5.61 & Rasa & Pedas & 75 & 14.29 & $* *$ & 3.84 \\
\hline & & & Tidak pedas & 129 & & & \\
\hline \multirow[t]{2}{*}{ VII } & 5.80 & Bau & Menyengat & 136 & 22.67 & $* *$ & 3.84 \\
\hline & & & Sedang & 68 & & & \\
\hline
\end{tabular}

Keterangan: $\varnothing=$ Diameter, $*$ Beda nyata dengan tingkat kepercayaan $\alpha=0.05$, ** $\alpha=0.01$. 
Tabel 3. Tingkat kepentingan dan preferensi konsumen pada atribut kualitas kenikir

\begin{tabular}{|c|c|c|c|c|c|c|c|}
\hline \multicolumn{2}{|c|}{ Urutan Kepentingan } & \multirow{2}{*}{ Atribut Kualitas } & \multirow{2}{*}{ Kategori } & \multirow[b]{2}{*}{$\mathrm{n}$} & \multirow{2}{*}{\multicolumn{2}{|c|}{$\chi$ Hitung }} & \multirow{2}{*}{$\chi$ Tabel } \\
\hline Peringkat & Rerata & & & & & & \\
\hline \multirow[t]{2}{*}{ I } & 1.98 & Warna daun & Hijau tua & 68 & 16.33 & $* *$ & 3.84 \\
\hline & & & Hijau muda & 124 & & & \\
\hline \multirow[t]{2}{*}{ II } & 2.20 & Jumlah daun & Banyak & 154 & 70.08 & $* *$ & 3.84 \\
\hline & & & Sedang & 38 & & & \\
\hline \multirow[t]{2}{*}{ III } & 4.29 & Bunga & Ada bunga & 67 & 58.28 & $* *$ & 3.84 \\
\hline & & & Tidak ada bunga & 125 & & & \\
\hline \multirow[t]{3}{*}{ IV } & 4.41 & $\mathrm{Bau}$ & Menyengat & 67 & 27.41 & $* *$ & 5.99 \\
\hline & & & Sedang & 92 & & & \\
\hline & & & Tidak Berbau & 33 & & & \\
\hline \multirow[t]{3}{*}{ V } & 4.76 & Jumlah & Banyak & 102 & 63.88 & $* *$ & 5.99 \\
\hline & & cabang/tangkai & Sedikit & 76 & & & \\
\hline & & & Tidak bercabang & 14 & & & \\
\hline \multirow[t]{2}{*}{ VI } & 4.80 & Tekstur batang & Berserat & 64 & 21.33 & $* *$ & 3.84 \\
\hline & & & Tidak berserat & 128 & & & \\
\hline \multirow[t]{2}{*}{ VII } & 5.55 & Rasa & Getir & 81 & 4.69 & $*$ & 3.84 \\
\hline & & & Tidak getir & 111 & & & \\
\hline
\end{tabular}

Keterangan: * Berbeda nyata pada tingkat kepercayaan $\alpha=0.05$, ** $\alpha=0.01$.

Hasil uji atribut kenikir yang meliputi warna daun, jumlah daun, ada tidaknya bunga, bau, jumlah cabang/tangkai, dan tekstur batang menunjukkan adanya perbedaan yang nyata $(\alpha$ $=0.01)$, untuk hasil uji rasa berbeda nyata $(\alpha=$ 0.05). Bisa disimpulkan bahwa konsumen mempunyai preferensi/selera tertentu pada kualitas atribut kenikir. Sesuai dengan preferensinya, mayoritas responden menginginkan kenikir berdaun hijau muda, berjumlah daun banyak, tidak berbunga, bau sedang, jumlah cabang/tangkai banyak, tekstur batang tidak berserat, dan rasa tidak getir.

Untuk mendapatkan sayuran kenikir yang sesuai dengan preferensi atribut kualitas di atas dapat dilakukan dengan beberapa teknik budidaya: (1) daun berwarna hijau muda diperoleh ketika panen dilakukan pada pucuk tanaman, (2) jumlah dan tangkai daun banyak didapat ketika sering melakukan pangkas produksi, (3) tidak memiliki bunga didapat ketika panen dilakukan sebelum tanaman memasuki umur berbunga, (4) berbau sedang didapat ketika tanaman tidak tercekam, (5) tekstur batang tidak berserat didapat ketika tanaman dipanen pada batang tanaman yang masih muda, dan (6) Rasa tidak getir didapat apabila kenikir dipanen yang masih muda. Selain teknik budidaya, dapat juga dilakukan perakitan varietas kenikir oleh para pemulia sesuai dengan preferensi atribut kualitas di atas.

\section{Selada Air}

Tingkat kepentingan dan preferensi konsumen pada atribut kualitas selada air disajikan pada Tabel 4. Dari tingkat kepentingan (ranking) tersebut, konsumen memposisikan warna daun pada pertimbangan pertama untuk memilih/membeli selada air. Peringkat kedua dan ketiga yang menjadi pertimbangan konsumen untuk membeli selada air yaitu jumlah daun, ukuran batang, kekerasan daun dan rasa.

Hasil uji sifat kualitas selada air yang mencangkup warna daun, jumlah daun, ukuran batang, kekerasan daun serta rasa terlihat adanya beda nyata $(\alpha=0.01)$. Hasil tersebut mengindikasikan jika konsumen memiliki preferensi/selera tertentu terhadap kualitas atribut selada air. Sesuai preferensinya konsumen lebih menyukai daun selada air berwarna daun muda. Peringkat kedua dan ketiga yang menjadi pertimbangan konsumen yaitu jumlah daun banyak serta ukuran batang sedang. Selanjutnya berturut-turut kekerasan daun yang lunak serta rasa agak manis. Berdasarkan data wawancara menunjukkan bahwa selada air yang berwarna daun hijau muda serta kekerasan daun lunak lebih disukai, karena menurut konsumen daun berwarna hijau tua dan daun yang tidak lunak sudah tidak layak dikonsumsi.

Untuk mendapatkan sayuran selada air yang sesuai dengan preferensi atribut kualitas di atas dapat dilakukan dengan beberapa teknik budidaya: (1) daun berwarna hijau muda diperoleh ketika panen dilakukan saat tanaman masih muda, dan (2) jumlah daun banyak, ukuran batang medium, kekerasan daun lunak serta rasa agak manis didapat ketika tanaman 
dipanen pada umur muda. Selain teknik budidaya, dapat juga dilakukan perakitan varietas selada air oleh para pemulia sesuai dengan preferensi atribut kualitas di atas.

Preferensi atribut kualitas ketiga komoditas sayuran indigenous di atas bisa didapat oleh petani ketika melakukan pembudidayaan secara intensif. Walaupun pada awalnya dirasa tidak mudah untuk melakukannya, tetapi ketika sudah berjalan menjadi suatu kebiasaan, maka hal tersebut menjadi lebih mudah.

\section{Frekuensi, Waktu Terakhir dan Kendala dalam Konsumsi Sayuran Indigenous}

Selada air termasuk macam sayuran yang sedikit dikenal dan tidak sering dikonsumsi konsumen. Kenikir merupakan sayuran yang cukup dikenal konsumen. Berbeda dengan sayuran kemangi yang sudah dikenal oleh konsumen. Rerata frekuensi konsumsinya yaitu sering (46.41\%), responden mengonsumsi kemangi sekitar 1-2 kali seminggu, serta dari waktu mengonsumsi terakhir, sebagian besar responden $(54.33 \%)$ mengonsumsi kemangi sekitar 1-6 hari lalu.

Tabel 4. Tingkat kepentingan dan preferensi konsumen pada atribut kualitas selada air

\begin{tabular}{|c|c|c|c|c|c|c|c|}
\hline \multicolumn{2}{|c|}{ Urutan Kepentingan } & \multirow{2}{*}{$\begin{array}{c}\text { Atribut } \\
\text { Kualitas }\end{array}$} & \multirow{2}{*}{ Kategori } & \multirow{2}{*}{$\mathrm{n}$} & \multirow{2}{*}{\multicolumn{2}{|c|}{$\chi$ Hitung }} & \multirow{2}{*}{$\chi$ Tabel } \\
\hline Peringkat & Rerata & & & & & & \\
\hline \multirow{3}{*}{ I } & \multirow{3}{*}{1.48} & \multirow{3}{*}{$\begin{array}{l}\text { Warna } \\
\text { Daun }\end{array}$} & Hijau tua & 32 & 69.92 & $* *$ & 5.99 \\
\hline & & & Hijau muda & 94 & & & \\
\hline & & & Hijau kekuningan & 17 & & & \\
\hline \multirow{2}{*}{ II } & \multirow{2}{*}{2.48} & Jumlah & Banyak & 115 & 52.93 & $* *$ & 3.84 \\
\hline & & Daun & Sedang & 28 & & & \\
\hline \multirow{3}{*}{ III } & \multirow{3}{*}{3.15} & \multirow{3}{*}{$\begin{array}{l}\text { Ukuran } \\
\text { Batang }\end{array}$} & Besar & 27 & 28.59 & $* *$ & 5.99 \\
\hline & & & Sedang & 77 & & & \\
\hline & & & Kecil & 39 & & & \\
\hline \multirow{3}{*}{ IV } & \multirow{3}{*}{3.82} & \multirow{3}{*}{$\begin{array}{l}\text { Kekerasan } \\
\text { Daun }\end{array}$} & Lunak & 115 & 23.78 & $* *$ & 5.99 \\
\hline & & & Kenyal & 14 & & & \\
\hline & & & Renyah & 14 & & & \\
\hline \multirow{3}{*}{ V } & \multirow{3}{*}{4.07} & \multirow{3}{*}{ Rasa } & Agak pahit & 42 & 16.97 & $* *$ & 5.99 \\
\hline & & & Agak manis & 70 & & & \\
\hline & & & Lainnya & 31 & & & \\
\hline
\end{tabular}

Keterangan: ** Berbeda nyata pada tingkat kepercayaan $\alpha=0.01$.

Tabel 5. Frekuensi, waktu terakhir dan kendala mengonsumsi sayuran indigenous

\begin{tabular}{|c|c|c|c|c|c|c|}
\hline \multirow{3}{*}{$\begin{array}{l}\text { Frekuensi, Waktu Terakhir dan Kendala Mengonsumsi } \\
\text { Sayuran Indigenous }\end{array}$} & \multicolumn{6}{|c|}{ Komoditas } \\
\hline & \multicolumn{2}{|c|}{ Kemangi } & \multicolumn{2}{|c|}{ Kenikir } & \multicolumn{2}{|c|}{ Selada air } \\
\hline & $\Sigma$ & $\%$ & $\Sigma$ & $\%$ & $\Sigma$ & $\%$ \\
\hline \multicolumn{7}{|l|}{ Frekuensi konsumsi } \\
\hline Sering: $1-2$ kali seminggu & 97 & 46.41 & 46 & 22.44 & 48 & 26.23 \\
\hline Cukup sering: 1 kali 2 minggu & 34 & 16.27 & 53 & 25.85 & 31 & 16.94 \\
\hline Jarang: 1 kali sebulan atau lebih & 72 & 34.45 & 68 & 33.17 & 49 & 26.78 \\
\hline Tidak pernah & 6 & 2.87 & 38 & 18.54 & 55 & 30.05 \\
\hline \multicolumn{7}{|l|}{ Waktu terakhir mengonsumsi } \\
\hline 1-6 hari lalu & 113 & 54.33 & 50 & 27.47 & 47 & 31.33 \\
\hline 1-4 minggu lalu & 40 & 19.23 & 74 & 40.66 & 35 & 23.33 \\
\hline $1-6$ bulan lalu & 49 & 23.56 & 39 & 21.43 & 39 & 26.00 \\
\hline$>6$ bulan lalu & 6 & 2.88 & 19 & 10.44 & 29 & 19.33 \\
\hline \multicolumn{7}{|l|}{ Kendala mengonsumsi } \\
\hline Rasa yang tidak enak & 33 & 15.07 & 37 & 18.14 & 2 & 1.32 \\
\hline Menu masakan terbatas & 62 & 28.31 & 69 & 33.82 & 22 & 14.47 \\
\hline Ketersediaan sayuran di tempat pembelian tidak selalu ada & 27 & 12.33 & 33 & 16.18 & 61 & 40.13 \\
\hline Pantangan & 3 & 1.37 & 2 & 0.98 & 5 & 3.29 \\
\hline Tidak komentar & 94 & 42.92 & 63 & 30.88 & 62 & 40.79 \\
\hline
\end{tabular}


Dari total responden, 33.17\% mengatakan jarang mengonsumsi kenikir, dan 30.05\% mengatakan tidak pernah mengonsumsi selada air. Berdasarkan waktu terakhir mengonsumsinya, 31.33-54.33\% mengonsumsi kemangi dan selada air sekitar 1-6 hari lalu, $40.66 \%$ mengonsumsi kenikir 1-4 minggu dari terakhir kali mengkonsumsi. Data ini menunjukkan kedua macam sayuran tersebut (kenikir serta selada air), pemanfaatannya sebagai sumber gizi, vitamin dan serat pada menu makanan sehari-hari oleh konsumen belum maksimal. Jika dilihat dari aspek harga, kedua sayuran tersebut mempunyai harga yang terjangkau/murah. Frekuensi, waktu terakhir dan kendala dalam konsumsi sayuran indigenous disajikan pada Tabel 5.

Kendala pemanfaatan sayuran indigenous oleh konsumen diantaranya ialah (1) pengetahuan konsumen tentang pengolahan sayuran tersebut kurang, menu masakan pada sayuran kenikir terbatas, (2) ketersediaan sayuran di tempat pembelian tidak selalu ada, sayuran selada air bersifat musiman.

Kendala pemanfaatan sayuran indigenous oleh konsumen dapat dijadikan pertimbangan untuk mengembangkan sayuran tersebut. Pengembangannya harus didukung dengan teknologi pengolahan hasil pangan. Tujuannya untuk menganekaragamkan menu masakan yang berbahan dasar sayuran indigenous. Upaya pengembangan lain yaitu menjamin ketersediaan sayuran indigenous di tempat pembelian, dengan cara membudidayakan sayuran tersebut secara intensif. Sehingga sayuran dapat dipanen di luar musim dan selalu tersedia di pasar.

\section{KESIMPULAN}

Preferensi konsumen terhadap atribut kualitas tergantung pada jenis sayurannya. Sayur kemangi yang disukai adalah memiliki warna daun muda, jumlah daun banyak, ukuran daun medium (garis tengah $3.5 \mathrm{~cm}$ ), tidak terdapat bunga, total cabang/tangkai lebat, rasa tidak pedas, dan berbau menyengat. Sayur kenikir yang disukai adalah warna daun muda, jumlah daun banyak, tidak terdapat bunga, berbau sedang, jumlah cabang/tangkai banyak, tekstur batang tidak berserat, dan rasa tidak getir. Sayur selada air yang disukai adalah warna daun muda, jumlah daun banyak, ukuran tangkai sedang, berdaun lunak, dan rasa agak manis.

\section{UCAPAN TERIMAKASIH}

Riset ini dibiayai dari Hibah Penelitian Terapan Unggulan Perguruan Tinggi, Kementrian Riset, Teknologi, dan Pendidikan Tinggi dengan kontrak penelitian No: 063/SP2H/LT/DRPM/IV/2017 serta No: 063/ADD/SP2H/LT/DRPM/VIII/2017.

\section{DAFTAR PUSTAKA}

Adiyoga, W., Nurmalinda. 2012. Analisis konjoin preferensi konsumen terhadap atribut produk kentang, bawang merah, dan cabai merah. J. Hort. 22(3): 292-302.

Ameriana, M., W. Adiyoga, L. Sulistyowati. 1998. Pola konsumsi dan selera konsumen cabai dan kentang di tingkat lembaga. J. Hort. 8(3): 1233-1241.

D’Anna, F., L. Sabatino. 2013. Morphological and agronomical characterization of eggplant genetic resources from the Sicily area. J. Food, Agriculture Environment. 11(1): 401-404.

Dias, J.S. 2012. Nutritional quality and health benefits of vegetables: A Review. Food and Nutr. Sci. 3: 1354-1374.

Hussin, S.R., W.F. Yee, J. Boyei. 2010. Essential quality attributes in fresh produce purchase by Malaysian consumers. J. Agribussiness Marketing 3: $1-19$.

Irfai, I. 2013. Efektifitas pemberian kenikir (Cosmos caudatus Kunth.) terhadap bobot karkas, organ pencernaan, hati dan kolestrol daging ayam kampung (Gallus gallus domesticus). Skripsi. Institut Pertanian Bogor. Bogor. p. 15. 
Keatinge, J.D.H., J.F. Wang, F.F. Dinssa, A.W. Ebert, J.d'A. Hughes, T. Stoilova, N. Nenguwo, N.P.S. Dhillon, W.J. Easdown, R. Mavlyanova, A. Tenkouano, V. Afari-Sefa, R. Y. Yang, R. Srinivasan, R. J. Holmer, G. Luther, F.I. Ho, A. Shahabuddin, P. Schreinemachers, E. Iramu, P. Tikai, A. DakuidreketiHickes, M. Ravishankar. 2015. Indigenous vegetables worldwide: their importance and future development. Acta Hortic. 1102: 1-20.

Kwenin, W.K.J., M. Wolli, B.M. Dzomeku. 2011. Assessing the nutritional value of some African indigenous green leafy vegetables in Ghana. J. Animal Plant Sci. 10(2): 1300-1305.

Maghfoer, M.D., N. Aini, W. Sumiya, K. Yurlisa. 2017. Eksplorasi potensi sayuran indigenous di Provinsi Jawa Timur. Laporan akhir tahun Penelitian Terapan Unggulan Perguruan Tinggi. Tidak dipublikasikan.

Mardiyani, S.A., N. Khoiriyah, C. Khuluk. 2017. Kajian morfologis dan fungsional 5 sayuran indigenous minor sebagai sumber nutrisi berbasis kearifal lokal di wilayah Malang Raya. Prosiding Seminar Nasional Hasil Penelitian Sosial Ekonomi Pertanian. Keberlanjutan Agribisnis Indonesia di Era Globalisasi: Liberalisasi atau Proteksi. p. 238-244.

Matenge, S.T.P., D.V.D. Merwe, H.D. Beer, M.J.C. Bosman, A. Kruger. 2012. Consumers beliefs on indigenous and traditional foods and acceptance of products made with cow pea leaves. Afr. J. Agric. Res. 7(14): 2243-2254.

Mottaleb, K. A. 2018. Perception and adoption of a new agricultural technology: Evidence from a developing country. Tech. in Society. 55: 126-135.

Pariona, A. 2018. The World's 17 Megadiverse Countries. https://www.worldatlas.com/ articles/ecologically-megadiverse-countriesof-the-world.html. [18 Desember 2018].

Salamah, E., S. Purwaningsih, E. Permatasari. 2011. Aktivitas antioksidan dan komponen bioaktif pada selada air (Nasturtium officinale L. R. Br.). J. Pengolahan Hasil Perikanan Indonesia. XIV(2): 85-91.

Santosa, E., U. Prawati, Sobir, Y. Mine, N. Sugiyama. 2015. Agronomy, utilization and economics of indigenous vegetables in West Java, Indonesia. J. Hort. Indonesia. 6(3): 125-134.

Siegel, S. 1997. Statistik Non Parametrik, untuk Ilmu-Ilmu Sosial. Gramedia Pustaka Utama. Jakarta. p. 52-58.

Soetiarso, T.A. 2010. Sayuran indigenous: alternatif sumber pangan bernilai gizi tinggi. Balai Penelitian Tanaman Sayuran, Pusat Penelitian dan Pengembangan Hortikultura, Badan Penelitian dan Pengembangan Pertanian, Departemen Pertanian. p. 5-10. 